\title{
CURRENT KNOWLEDGE OF METHICILLIN-RESISTANT STAPHYLOCOCCUS AUREUS AND COMMUNITY-ASSOCIATED METHICILLIN-RESISTANT STAPHYLOCOCCUS AUREUS
}

\author{
Ivanka Matouskova, Vladimir Janout
}

\author{
Department of Preventive Medicine, Faculty of Medicine and Dentistry, Palacky University, Hnevotinska 3, 775 15 Olomouc, \\ Czech Republic \\ e-mail:matouski@tunw.upol.cz
}

Received: April 17, 2008; Accepted: August 5, 2008

Key words: Methicillin resistant Staphylococcus aureus(MRSA)/Community-associated MRSA (CA-MRSA)/Hospital-associated MRSA (HA-MRSA)/Active surveillance

Background: Bacterial strains that are oxacillin and methicillin-resistant, historically termed methicillin-resistant Staphylococcus aureus (MRSA) are resistant to all B-lactam agents, including cephalosporins and carbapenems. MRSA are pathogenic and have a number of virulence factors that enable them to result in disease. They are transmissible and important causes of nosocomial infections worldwide. An MRSA outbreak can occur when one strain is transmitted to other patients or through close contacts of infected persons in the community. Hospital-associated MRSA (HA-MRSA) isolates are also frequent causes of healthcare-associated bloodstream and catheter-related infections. Community-associated MRSA (CA-MRSA) isolates are often only resistant to beta-lactam agents and erythromycin but they are an emerging cause of community-associated infections, ecpecially skin and soft tissue infections (SSTI) and necrotizing pneumonia.

Methods: Current possibilities for detecting MRSA strains in the laboratory are reviewed and discussed in the context of the recent literature.

Results and Conclusion: The active surveillance and prevention of MRSA occurence and spreading in hospitals are discussed in the context of recent literature.

\section{Staphylococcus aureus}

Staphylococci are very widespread bacteria. Their main representative, Staphylococcus aureus subsp. aureus, is one of the most important and successful human pathogens. According to current knowledge, the Staphylococcus genus has 50 taxons with 39 various types and several subtypes ${ }^{1}$.

Staphylococcus aureus ( $S$. aureus) is among the most ubiquitous of bacteria. It is highly resistant to adverse environmental conditions and it resists drying as well as high $\mathrm{NaCl}$ concentrations. This enables a probably temporary and even permanent colonization of skin and nasal mucosa.

$S$. aureus has been detected as a carrier strain in the nasal mucosa of the general population with a mean carriage rate of $37.2 \%$. However, the range of carriage rates is large. This may be due partly to differences in the quality of the sampling and of the culture techniques used in these studies ${ }^{2}$. Two billion individuals are estimated to be carrying $S$. aureus, worldwide. Persons colonized with $S$. aureus are at increased risk for subsequent infections ${ }^{3}$. Probably $1 \%$ of these are MRSA colonised ${ }^{4,5}$. S. aureus is also present in the skin and mucosae of various animals, and it is also found in the environment, especially around people, animals, and in food.

The $S$. aureus strains produce a number of extracellular enzymes (coagulase, hyaluronidase [spreading factor], penicillinase etc.) and toxins (haemolysins, staphylococcal super antigens and leukocidins), which function as virulence factors ${ }^{6}$. Among leukocidins, the Panton-Valentin leukocidin is currently the focus of considerable attention in connection with community-associated strains resistant to methicillin (CA-MRSA) which produce it. The PantonValentin leukocidin was described in 1932 and bears the name of its discoverers - Panton and Valentin ${ }^{7}$. In the literature the abbreviations PVL and Luk-PV are also used. In this case, a cytotoxin forms heptameric pores in the leukocyte membrane and this destroys the leukocyte. PVL consists of two components that are, depending on their relative speed during the chromatographic division, identified as fast $(\mathrm{F})$ and slow $(\mathrm{S})^{8}$. PVL increases the virulence of $S$. aureus. PVL-carrying strains can cause recurrent, chronic and particularly severe skin and softtissue infections as well as rapidly fatal pneumonia which occur notably in previously healthy, immunocompetent individuals ${ }^{9}$. However, its role as a virulence determinant has recently been disputed ${ }^{10}$. These MRSA strains are called community-associated MRSA (CA-MRSA). PVL production is a common trait among CA-MRSA, it is importatnt to recognise that PVL-negative strains can also occur $^{11}$. Zhang with his colleagues state: "the specific role that PVL plays in the epidemiological features and pathogenesis of CA-MRSA infections has remained undefined and controversial" ${ }^{12}$. 
When the host is weakened, a spectrum of diseases can occur, from minor skin inflammations (furuncles, impetigo), alimentary poisoning, osteomyelitis, toxic shock syndrome (TSS), staphylococcal scalded skin syndrome (SSSS) and bacterial endocarditis to life-threatening sepsis and pneumonia ${ }^{13}$. S. aureus is one of the major causes of human infections which originate both in connection with staying in a hospital or outside of it. According to the authors Boyle-Vavra and Daum, S. aureus is the most virulent of the Staphylococcus genus, representing the most frequent pathogen in biological material isolated from in-patients, and in out-patients it is the second most frequent isolated pathogen ${ }^{14}$.

\section{Era of antibiotics}

The high mortality rate connected to the $S$. aureus strain decreased only in the forties of the last century after the first antibiotic - penicillin - was introduced into staphylococcal infection treatment. Sir Alexander Fleming could not have foreseen that his discovery of penicillin would also trigger global problems: resistant and multidrug resistant bacterial strains emerged at this moment. Towards the end of 1940, hospitals in England and the USA reported that up to $50 \%$ of $S$. aureus strains registered penicillin resistance ${ }^{15}$. Clinical trials have demonstrated the resistance which is caused by the penicillinase enzyme (B-lactamase) $)^{16,17}$.

It was phage typing, a brand new method that enabled identification of the $S$. aureus strain that was infectious, penicillin-resistant, and extremely invasive. The strain was first described in Australia and subsequently it spread fast to America (epidemics in maternity units) and to hospitals in the UK. The strain was termed the $80 / 81$ strain, according to its bacteriophage ${ }^{18}$. Decrease in the occurrence of this strain took place in the sixties when methicillin, the first semisynthetic penicillinasefast penicillin was introduced. The staphylococci needed a mere six months to create methicillin-resistant strains. In 1960, a screening of 5000 clinical isolates identified $3 S$. aures strains resistant to methicillin. All three of them had the same phenotype and came from the same hospital in the South of England ${ }^{19}$. In the medical literature there emerged an abbreviation - MRSA (methicillin-resistant Staphylococcus aureus) while in the English literature, the term HA-MRSA (healthcare-associated methicillin-resistant Staphylococcus aureus) is used.

From that time MRSA was considered to be the most important agent of hospital infections, both in adult and child patients ${ }^{20}$.

In the second half of the sixties, MRSA strains developed that were resistant to other antibiotics and the occurrence of multidrug-resistant MRSA was reported from several Central European countries, England, Australia and India. In 1971 in Denmark, MRSA strains with a combined resistance to penicillin, streptomycin, tetracycline and occasionally to erythromycin represented $15 \%$ of all isolated S. aureus strains. During the seventies and at the beginning of the eighties a decrease in these strains was registered (Denmark reported only $0.2 \%$ of
MRSA strains). The cause was not entirely clear but probably the change of prescribing streptomycin and tetracycline, and the introduction of strict preventive measures against spreading this infectious agent played a significant role $^{21}$.

In 1993 England and Wales registered only 47 deaths connected to the MRSA strains but in 1995 there were 377 deaths $^{22}$.

At the beginning of the eighties a gentamicin-resistant MRSA strain was reported. The findings were confirmed by two European countries (England and Ireland) and also by the USA. One health-care worker was believed to have imported the multidrug-resistant MRSA strain to England from Australia ${ }^{23}$.

Vancomycin was first approved by the Food and Drug Administration in 1958, and resistance first emerged in coagulase-negative staphylococci in 1987 (ref. ${ }^{24}$ ). In 1996, the first clinical isolate of $S$. aureus with reduced susceptibility to vancomycin was identified in Japan (vancomycin-intermediate $S$. aureus $=$ VISA) ${ }^{25}$. In July 1997 the Center for Disease Control and Prevention (CDC) issued an interim recommendation regarding prevention and control of these strains ${ }^{26}$. In June 2002, a strain of $S$. aureus fully resistant to vancomycin (vancomycin-resistance $S$. aureus = VRSA) was isolated from a patient in Michigan ${ }^{27}$. Conjugate transfer for the vanA gene from enterococci to $S$. aureus had previously been demonstrated in vitro ${ }^{28}$. Among enterococci, four phenotypes of glycopeptide resistance have been reported in the literature: vanA phenotype with high-level resistance to vancomycin and teicoplanin, $v a n B$ phenotype with resistance to vancomycin only, vanC phenotype and a "vanC-like" phenotype $^{29}$.

The above overview of the $S$. aureus strains' resistance to antibiotics, concerns so-called hospital-associated strains which have a major share in developing hospital infections.

\section{Genetics and the development of antibiotic resistance}

Resistance to methicillin and other B-lactam antibiotics is caused by the mecA gene, which is situated on the Staphylococcal Cassette Chromosome mec (SCCmec) $)^{30}$. The mecA gene encodes the 78-kDa penicillin-binding protein (PBP) 2a or PBP2' (ref. ${ }^{31}$ ). To date, five SCCmec types (I-V) have been distinguished, and several variants of these SCCmec types have been described. All SCCmec elements carry genes for resistance to B-lactam antibiotics, as well as genes for the regulation of the expression of $m e c A$. Additionally, SCCmec types II and III carry non- $3-$ lactam antibiotic resistance genes on integrated plasmids and a transposon. The history of MRSA ${ }^{32}$. (Table 1)

The epidemiology of MRSA strains makes use of, for their description, pulsed-field gel electrophoresis (PFGE), multilocus sequence typing (MLST), SCCmec typing (four methods are currently available for the characterisation) and typing of the variable tandem repeat region of protein A (spa Tyliny) ${ }^{33}$. Using these methods the prevalence of MRSA has been found to range from $0.6 \%$ in The Netherlands to $66.8 \%$ in $\operatorname{Japan}^{32}$. 
Table 1. The history of MRSA

\begin{tabular}{|c|l|}
\hline SCCmec & \multicolumn{1}{|c|}{ Date and state of an isolate } \\
\hline I & 1961 UK \\
\hline II & 1982 Japan (New York/Japan clone) \\
\hline III & 1985 New Zealand \\
\hline IV & spread round the world during the 1990s \\
\hline V & $\begin{array}{l}\text { at the beginning of the 21st century in } \\
\text { Australia }\end{array}$ \\
\hline
\end{tabular}

"Two opposing theories have been suggested to describe the relationship between the first MRSA isolates and recent MRSA clones: The single-clone theory suggests that all MRSA clones have a common ancestor, and that SCCmec was introduced only once into S. aureus. The multi-clone theory hypothesis presumes that the SCCmec was introduced several times into different $S$. aureus genetic lineages. The latter theory has now been supported by several studies" ${ }^{32}$.

\section{Community-associated MRSA}

The year 1993 marked the rise of a new clone of MRSA strains. These are called community-associated MRSA strains (CA-MRSA). They were isolated from indigenous Australian patients, original inhabitants of West Australia, who had no previous contact with a health-care system ${ }^{34}$. In the course of the last decade, information has emerged about the spread and isolation of these strains from different countries to almost all the continents of the world, in patients with no risk factor for nosocomial acquisition of MRSA. Community-associated MRSA (CA-MRSA) infections most commonly are skin and soft-tissue infections (SSTI); however, certain cases can progress to invasive tissue infections, bacteremia, and death ${ }^{35-55}$.

In three Czech strains of $S$. aureus, the presence of lukS-PV a lukF-PV genes were determined by the National Reference Laboratory in the year 2004 and found to belong to CA-MRSA ${ }^{56}$. Antimicrobial resistance tests and selected methods of molecular biology demonstrated that their characteristics differ from the multi-drug resistant HA-MRSA strains described in hospital patients ${ }^{14,39,57-70}$. The main characteristics of HA-MRSA and CA-MRSA strains are specified. (Table 2)

Skin soft-tissue infections caused by the CA-MRSA strains have been described mainly in young people and children, athletes, prisoners, and army recruits ${ }^{41,71-73}$.

There have also been cases of infection caused by CA-MRSA strains acquired in connection with staying in hospital ${ }^{52}$. In 2007 a paper was published reporting that with the help of retrospective investigation of $S$. aureus strain isolates from 1991-2003, there were identified MRSA strains with a CA-MRSA pattern at a child clinic already in $1991^{20}$.

Criteria for a probable infection caused by the community-associated MRSA (CA-MRSA) ${ }^{74}$.

- Diagnosis of MRSA was made in the outpatient setting or by a culture positive for MRSA within 48 hours after admission to the hospital

- No medical history of MRSA after admission to the hospital

Table 2. The main characteristics HA-MRSA and CA-MRSA strains

\begin{tabular}{|c|c|c|}
\hline Characteristic & HA-MRSA & CA-MRSA \\
\hline Clinical & $\begin{array}{l}\text { surgical site infections, } \\
\text { invasive }\end{array}$ & $\begin{array}{l}\text { skin infections, "bug bites", } \\
\text { rarely invasive, multiple, recurrent }\end{array}$ \\
\hline Epidemiology & old, healthcare & $\begin{array}{l}\text { young, athletes, drug users, } \\
\text { correctional facilities and military }\end{array}$ \\
\hline Antibiotic resistance & multi-drug resistant & $\beta$-lactam resistant \\
\hline Molecular markers & $\begin{array}{l}\text { PVL - } \\
\text { SCCmec I-III }\end{array}$ & $\begin{array}{l}\text { PVL + } \\
\text { SCCmec IV, V }\end{array}$ \\
\hline
\end{tabular}

Table 3. Definitions used for epidemiologic classification of invasive methicillin-resistant Staphylococcus aureus (MRSA) infections

\begin{tabular}{|l|l|}
\hline Classification & Definition \\
\hline Health care-associated & \\
\hline Community-onset & $\begin{array}{l}\text { Cases with at least 1 of the following health care risk factors: } \\
\text { 1) presence of an invasive device at time of admission, } \\
\text { 2) history of MRSA infection or colonization, } \\
\text { 3) history of surgery, hospitalization, dialysis, or residence in a long-term care facility in } \\
\text { previous 12 months preceding culture date. }\end{array}$ \\
\hline Hospital-onset & $\begin{array}{l}\text { Cases with positive culture result from a normally sterile site obtained }>48 \mathrm{~h} \text { after hospital } \\
\text { admission. These cases might also have } \geq 1 \text { of the community-onset risk factors. }\end{array}$ \\
\hline Community-associated & \begin{tabular}{l} 
Cases with no documented community-onset health care risk factor. \\
\hline
\end{tabular}
\end{tabular}


- No medical history of MRSA infection or colonization

- No medical history in the past year of:

- Hospitalization

- Admission to a nursing home, skilled nursing facility, or hospice

- Dialysis

○ Surgery

- No permanent indwelling catheters or medical devices that pass through the skin into the body

In the majority of the published studies, there is missing a clinical and epidemiological classification of invasive infections induced by MRSA strains (HA-MRSA and CA-MRSA). The recent characteristics are shown in table $3^{75}$.

"Health care-associated infections, in turn, have been classified as either community-onset (cases with a health care risk factor but with a culture obtained $\leq 48$ hours after hospital admission) and hospital-onset (cases with a culture obtained $>48$ hours after admission, regardless whether they also had other health care risk factors)" ${ }^{75}$.

\section{Laboratory diagnostics of Methicillin-Resistant Staphylococcus aureus (MRSA)}

The National Committee for Clinical Laboratory Standards (NCCLS), now called the Clinical and Laboratory Standards Institute (CLSI), recommends the cefoxitin disk screen test, the latex agglutination test for PBP2a, or a plate containing $6 \mathrm{ug} / \mathrm{ml}$ of oxacillin in Müeller-Hinton agar supplemented with $\mathrm{NaCl}(4 \%$ $\mathrm{w} / \mathrm{v} ; 0.68 \mathrm{~mol} / \mathrm{l}$ ) as alternative methods of testing for $\mathrm{MRSA}^{76}$.

Accurate detection of oxacillin/methicillin resistance can be difficult, due to the presence of two subpopulations (one susceptible and the other resistant) that may coexist within a culture of staphylococci. All the cells in a culture may carry the genetic information for resistance, but only a small number may express the resistance in vitro. This phenomenon is termed heteroresistance. Cells expressing heteroresistance grow more slowly than the oxacillin-susceptible populations and may be missed at temperatures above $35{ }^{\circ} \mathrm{C}$. For this reason, CLSI recommends incubating isolates being tested against oxacillin, methicillin, or nafcillin at $33-35^{\circ} \mathrm{C}$ (maximum of $35^{\circ} \mathrm{C}$ ) for a full 24 hours before reading ${ }^{76}$.

Nucleic acid amplification tests, such as the polymerase chain reaction (PCR), can be used to detect the mecA gene, which mediates oxacillin resistance in staphylococci. Staphylococcal resistance to oxacillin/methicillin occurs when an isolate carries an altered penicillin-binding protein, PBP2a, which is encoded by the mecA gene ${ }^{31,32}$.

The classic microbiological methods (microscopy, cultivation, biochemical identification) are procedures that enable identification of bacteria strains within 24-96 hours. They are not suitable for active surveillance of the MRSA strains spreading in hospitals or for rapid identification of serious bacteremia. Microbiologists strive to prepare kits for rapid and reliable identification of the MRSA strains in carriers, and for detecting the presence of these strains in infections. Not all laboratories however are equipped with recent molecular biological instruments and methods. For direct identification of MRSA strains, it is recommended that these clinical microbiology laboratories use chromogenic selective media and subsequent confirmation tests of the MRSA strains (agglutination tests for testing for PBP2a), or a plate containing $6 \mathrm{ug} / \mathrm{ml}$ of oxacillin ${ }^{77}$. The following are the most frequent and laboratory verified chromogenic media.

MRSASELECT - a selective chromogenic medium designed for isolation and direct identification of the methicillin-resistant Staphylococcus aureus strain (MRSA). Pink colonies grow within 18-24 hours and all the other microorganisms are inhibited. The test specificity is $99.8 \%$ and its sensitivity is $98.9 \%$ (ref. ${ }^{77}$ ). Studies in which researchers compared the sensitivity and specificity of a number of types of chromogenic cultivation media for isolating the MRSA strains have confirmed the data by the producer of the above mentioned media ${ }^{78-81}$. A Dutch author van Loo and his colleagues stress the fact that in connection with a prolonged incubation (from 20 to 48 hours) there is an increase in false-positive (pink) colonies ${ }^{79}$. Also the work by Swiss authors considers the MRSASELECT medium more sensitive than the media containing oxacillin designed for screening. I believe their comment is important and therefore I am citing them: „However, their respective performances under real conditions of utilization are heterogeneous, underlining the absence of gold standard medium for MRSA screening" $"$.

Oxacillin Resistance Screening Agar Base (ORSAB) is intended as a medium for the screening for methicillin resistant Staphylococcus aureus (MRSA) directly from routine swab samples. The screening of patients and staff for the early detection of MRSA colonisation is essential if epidemics are to be prevented. ORSAB is a novel medium which uses aniline blue to detect mannitol fermentation creating intense blue colonies of presumptive MRSA $^{82,83}$. Using this cultivation medium, after $24 \mathrm{hrs}$ (48 hrs) Apfalter et al found a sensitivity of $51 \%$ (68 \%) and a specificity of $96 \%(95 \%)$. Within the context of the detected values they draw attention to the existence of mannitol-negative $S$. aureus strains and mannitol-positive methicillin-resistant coagulase-negative staphylococci ${ }^{84}$.

ChromID MRSA is a new chromogenic medium for the rapid and reliable screening of methicillin-resistant Staphylococcus aureus (MRSA). Direct identification of MRSA strains is based on spontaneous green coloration of alpha-glycosidase-producing colonies (patent pending) and the presence of an antibiotic, cefoxitin. Immediate identification of MRSA = green colonies is possible after 18-24 hours of incubation ${ }^{85}$. This chromogenic medium was also assessed as the best by both English and Belgian authors compared to the others in use (including even the ORSAB medium $)^{86,87}$. Compernolle and his colleagues recommend using the Gram-stain and direct Pastorex Staph as well plus the latex agglutination test for positive colonies $^{87}$.

Microbes, especially MRSA strains are now a global problem linked to high mortality, morbidity and high hospital costs. Methods for rapid identification of MRSA 
strains are needed for targeted control of admitted patients, staff and environment so that these strains are not transmitted from patient to patient, especially through indirect transmission caused by the unwashed hands of health-care workers.

At present, a number of methods are described that use molecular biology findings for rapid detection of the MRSA strains. Most of these are based on the PCR multiplex for detecting genes that identify the $S$. aureus strains ( nuc gene and mecA gene). The nuc gene that encodes the thermostable nuclease of $S$. aureus. Thermostable nuclease is a protein with a molecular mass of $17,000 \mathrm{Da}$ (ref. ${ }^{88}$ ). MRSA originates from the introduction of a large mobile genetic element - Staphylococcal Cassette Chromosome mec ( $\mathrm{SCCmec}$ ) into a methicillin-susceptible $S$. aureus strain. These methods can be used only with clear staphylococci colonies but not for direct examination of e.g. nose swabs. Here false-positive results can be obtained because there are coagulase-negative staphylococci strains that carry the mecA gen. For maximum shortening of the time needed for examining the MRSA strains it is necessary to have kits available that will enable an analysis: $1 /$ directly from the executed swabs. This predominantly concerns detecting the MRSA strain carriers when admitted to high-risk departments (cardio surgery, vascular surgery, burn centres etc.) and 2/ of positive blood cultures in the Bactec system from patients suffering from bacteremia. Recently published studies deal with comparing the "IDI-MRSA real-time PCR assay" (Infectio Diagnostic, Sainte-Foy, Canada) kit with other procedures already in use. The studies' results show it to be the most sensitive kit for locating the MRSA strains in nose swabs (sensitivity of $92 \%$ ) when compared to other methods. The processing time is 2-4 hours in comparison to 3 days needed for chromogenic cultivation methods ${ }^{89-93}$. The StaphSR assay (BD GeneOhm, San Diego, CA) is a multiplex real-time PCR assay, for the identification and differentiation of methicillin-susceptible $S$. aureus (MSSA) and methicillinresistant $S$. aureus (MRSA) from positive blood cultures ${ }^{94}$. MRSA bacteremia is associated with significantly higher mortality than MSSA bacteremia ${ }^{95,96}$.

\section{Prevention of the MRSA occurrence and its spreading Patient screening}

According to Girou et al., colonized and infectious patients are the most important reservoir of MRSA in hospitals ${ }^{97}$. Śrámová draws attention to the fact that the border between colonization and infection is often unclear and must be determined by the attending physi$\operatorname{cian}^{98}$. When MRSA is detected in patients' palms, the possibility of MRSA contamination of their surrounding environmental surfaces is high ${ }^{99}$. Occurrence of MRSA colonized patients depends on the type of the department. In long-term care the colonization is much higher ${ }^{100,101}$. In a spinal unit it reaches $40-50 \%$ (ref. ${ }^{102}$ ). The literature reports that $35-84 \%$ of MRSA colonized patients fail to be identified by swabs that are ordered by doctors for clinical reasons ${ }^{97,100,101}$. It is recommended that swabs mainly of the anterior nares are taken - this screening should detect up to $80 \%$ of the MRSA carriers, and other swabs from additional body sites will increase the sensitivity to over $92 \%$ (ref. $^{2,97,102}$ ). MRSA carriers without any obvious infection are considered a serious reservoir of MRSA and it is assumed this infectious agent could be transmitted to other patients or health-care workers ${ }^{103}$. Studies that have found the prevalence of MRSA colonizing nasal mucosae report that this usually concerns people over 60 with no prior contact with a health centre. Nasal carriage of $S$. aureus and MRSA has been identified as a risk factor for the development of infections in various settings. This has been studied extensively in surgical patients, and in patients undergoing hemodialysis ${ }^{2,}{ }^{104-107}$. Human innate immune factors are crucial in nasal colonization by $S$. aureus $^{108}$. Cookson draws attention to different and often contradictory data on the carrying duration, risk factors connected to it, and even carrying associated with $\mathrm{HLA}^{36}$. It is recommended that selected hospital departments do a screening (a nasal swab) to detect MRSA prior to admitting a patient. This concerns mainly intensive care units, patients who are being prepared for vascular and cardio surgical operations, hemodialysis patients, and elderly patients ${ }^{104-107}$. However, the effectiveness of the "screening" cultivations for reducing the risk of transferring MRSA has not been proven in a randomized trial ${ }^{109}$. It is assumed that screening of admitted patients and of the exposed health-care workers contributes to the very low long-term prevalence of MRSA (1-3\%) occurrence in Dutch and Scandinavian hospitals ${ }^{110-113}$. Microbiologists from the South East England (long-term high prevalence of MRSA strains occurrence in hospitals) in their cohort study confirmed the need of a rapid detection of MRSA in patients in order to be able to significantly reduce the occurence and prevent its spread. The PCR method was launched into routine practice as an obligatory screening in adult patients that are being admitted to a surgical intensive care unit ${ }^{93,114-116}$. It is probably a question of time before the screening for the MRSA strains presence will become mandatory - given that transfer of a plasmid coding for resistance to antiseptics has been recorded ${ }^{117,118}$.

\section{Screening of health-care workers}

As published in the literature, nasal MRSA carriers among the health-care workers can be MRSA sources (transfer and spreading) but they are not considered as important a reservoir as the colonized or infectious patients. The nasal carrying in the health-care workers can be temporary. However, there is a risk of MRSA transfer to a patient, especially in hospitals where endemic strains of MRSA occur ${ }^{2,102,105}$. Different countries follow different recommendations: e.g. a short-term local application of antibiotics or strict observation of using personal protective equipment (mask, gloves, hand washing and hand disinfection). The health-care worker who comes into contact with colonized or infectious patients should regularly undergo screening for the MRSA strain presence ${ }^{119-121}$.

\section{Decolonization therapy}

Because $S$. aureus colonization is thought to lead to subsequent infection, decolonization is a potential 
strategy used for prevention. However, the effectiveness of CA-MRSA decolonization is unclear ${ }^{122}$.

There is no unambiguous opinion on bathing patients with disinfection preparations or local application of antibiotics ( $2 \%$ mupirocin) in case of nasal carriage of MRSA $^{123,124}$. An additional concern with routine use of mupirocin for nasal decolonization is the level of mupirocin resistance that has been observed with usage in MRSA endemic areas ${ }^{125}$. The plasmid-encoding mupirocin resistance has been found in the genome of the CA-MRSA strain, USA 300 (ref. ${ }^{126}$ ). We conclude that selective use of intranasal mupirocin and daily chlorhexidine bathing for patients with MRSA reduced the incidence of MRSA colonization and infection and contributed to reduction identified by active-surveillance cultures ${ }^{127}$. Wendt and his colleagues performed a double-blind, placebo-controlled clinical trial to compare the efficacy of whole-body washing with chlorhexidine combined with treatment with oral chlorhexidine rinse and nasal mupirocin with the efficacy of nasal mupirocin and oral chlorhexidine rinse alone. And conclusion: whole-body washing can reduce skin colonization, but it appears necessary to extend eradication measures to the gastrointestinal tract, wounds, and/or other colonized body sites if complete eradication is the goal $^{128}$.

\section{Isolation rooms and a barrier procedure}

If the hospital does not have special isolation rooms with a three-level air filtration system and prescribed pressure parameters ${ }^{129}$ then a single room is recommended, or it is possible to place several MRSA infected or colonized patients to one room - called a cohort ${ }^{117,130}$. The abovementioned ways of hospitalizing risky patients should be accompanied with so called hygienic sluice (the designated staff changes into apparel earmarked only for treating MRSA patients. The health-care workers should always use disposable gloves when dealing with a risk patient. No agreement has been reached in the literature as to whether health-care workers should use masks or not ${ }^{117,131,132}$.

The arrangement and technical equipment of isolation rooms and hygienic sluices are described in the literature $^{133}$. The Czech Republic handles the prevention and origin of hospital infections under Regulation 195/2005 Coll. currently in force ${ }^{134}$.

\section{Hand Washing and Hand Disinfection}

The risk of transferring MRSA strains is connected to temporary (transient) microflora. The amount and level of microbial types in the transient microflora of contaminated hands reflects the microbial load of the environment and the character of the executed work ${ }^{97}$. Contaminated hands are considered the most frequent way of transferring MRSA strains from health-care workers to patients. All prevention of transfer and spread the MRSA strains closely depends on using disposable gloves when treating MRSA infected patients. Hands are to be washed and disinfected prior to using the gloves and also after the attendance is over. The disposable gloves are to be disposed of. After washing, disinfecting liquid soap is recommended. For hand disinfection the most suitable preparations are the alcohol-based ones ${ }^{135-139}$. Christiaens et al. state that the level of transferring MRSA strains when using disinfection alcohol-based preparations decreased from 11.04 to 7.07 cases for every 1000 admitted patients ${ }^{136}$. Gordin and his colleagues report similar findings - they found an HA-MRSA strain decrease by $21 \%$ after a three-year usage of alcohol-based preparations for hand disinfection ${ }^{139,140}$.

Resistance to quaternary ammonium compounds (QAC) in staphylococci is common in hospital environments and has been described in the food industry, too. Resistance to quaternary ammonium-type antiseptic compounds, mediated by the $S$. aureus plasmid Psk1 is specified by an energy-dependent export mechanism encoded by the qacA gene. The $q a c B$ gene characteristically differs from $q a c A$ by conferring lower or no resistance to divalent organic cations ${ }^{141,142}$. The transfer of a plasmid coding for resistance to antiseptics has been confirmed. The $q a c A$ and $q a c B$ genes situated on the MRSA strain plasmid are responsible for antiseptics- resistance, and they are spread worldwide ${ }^{143,144}$. Attention is also drawn to the fact that the sensitivity of the MRSA strains to selected used biocides (e.g. chlorhexidine digluconate) has decreased. MRSA strains survive under lower concentrations than the stated minimum bactericidal concentration (MBC). Some authors stress the necessity to revise the used concentrations of some biocides owing to the fact that tests in vitro had been performed with clinical isolates of the MRSA strains ${ }^{144}$. An increase tolerance of the MRSA strains to chlorhexidine gluconate has been demonstrated as well ${ }^{145}$. In 2005 Australian researchers published the results of a time-restricted study (12 months) when in a university hospital with 840 beds and a high level of hospital infections induced by MRSA strains hand disinfection was introduced. It was a mix made according to the recipe of the authors Pitter et al. (70\% of isopropyl alcohol, $0.5 \%$ of chlorhexidine, skin emollient) ${ }^{146}$. A $40 \%$ reduction of isolated MRSA strains from the clinical material and a $57 \%$ reduction of bacteraemia - when the HA-MRSA strain was the agent - were detected ${ }^{102}$.

The hand washing and disinfection methods currently used in the Czech Republic are described ${ }^{147}$. Test method and requirements for chemical disinfection preparations and antiseptics are specified in the CSN EN ${ }^{148,149}$.

A combination of earlier detection of MRSA, isolation with selective patient decolonization, compliance with best professional practice, such as with hand hygiene and antibiotic stewardship, will reduce MRSA colonization and infection in the ICU, and given the severity of illness in such a group of patients. However, all these measures must be combined with adequate numbers of staff and suitable space and facilities ${ }^{150}$. Basic principles are essential for all hospitals.

\section{Cleaning and decontamination of the environment and the equipment}

The method and intensity of cleaning and decontamination of the environment predominantly depends on the 
type of department and on observing all the recommended procedures and on using personal protective equipment. The percentage of contaminated surfaces is reported to be between $64-74 \%$. The most frequently contaminated objects used by the patients include hospital beds and mattresses, bedding (bed sheets), grab bars along the walls, door handles, and taps ${ }^{136-143}$. When changing the bed sheets not only objects of a certain size but also infectious agent (MRSA) are released into the inner environment. The highest number was detected 15 minutes after this activity was executed. This shows that the MRSA strains circulate even in the inner environment ${ }^{151-154}$. As to various devices, keyboards are always stated as first $\mathrm{t}^{157}$, as to the medical equipment it is mainly the sleeves on the blood pressure gauges and tourniquets used for taking blood ${ }^{140}$. Contamination of stethoscope membranes by MRSA strains, and possibilities of subsequent patient-to-patient transmission are also treated. The percentages of positive findings vary. We believe that the results depend on the type of department (a cardio surgery intensive care unit, general practitioners, paediatric outpatient department) where the research was conducted. The information that the stethoscope membrane could be contaminated with MRSA must clearly lead to realizing that its regular disinfection is vital ${ }^{155-160}$. There is also a close link to the infection type. In case of respiratory infections the inner air becomes MRSA contaminated and subsequently also the surfaces ${ }^{148,149}$. For decontamination and a significant decrease of the MRSA strains occurrence on the working surfaces in nurses' rooms the authors recommend using rags impregnated with $80 \%$ ethyl alcohol ${ }^{161}$.

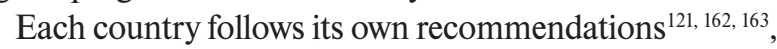
which in most cases ensue from the amended recommendations of CDC in Atlanta ${ }^{119}$. In the Czech Republic, in connection with the increase in MRSA strain prevalence in hospitals a recommendation has been drafted by a group of prominent experts. This contains a method for decontaminating the environment as well ${ }^{121}$.

Apart from antibiotics resistance, there can also be resistance to disinfection preparations ${ }^{143,144}$. Even in 2000 Jana Kneiflová et al described a $S$. aureus strain highly resistant to chlorine. The strain was found in the water of a swimming pool ${ }^{164}$.

In connection with a complete sequence of the MRSA strain genome (Mu50) a genus qacA was identified on the genome of the strain's plasmid. This causes resistance to biocides based on quarternary ammonium compounds ${ }^{165}$. In the literature, attention has been drawn to the increased tolerance and resistance of the MRSA strains to biocides containing this effective component ${ }^{145}$.

\section{The current situation in the Czech Republic}

The European Antimicrobial Resistance Surveillance System (EARSS), funded by the European Centre for Disease Prevention and Control of the European Commision is an international network of national surveillance systems. In the Czech Republic, antimicrobial resistance surveillance in invasive Staphylococcus aureus isolates within EARSS was started in July 2000. Analysis of blood isolates strains $S$. aureus collected in 2000-2005 showed increase in oxacillin resistance. Over the period, the MRSA incidence tripled from $3.8 \%$ to $12.5 \%$. These organisms spread rapidly in hospitals ${ }^{166,167}$.

\section{In conclusion}

"Methicillin-resistant Staphylococcus aureus (MRSA) is an important cause of nosocomial infection worldwide. Interpretation of community MRSA trends is problematical, in that the term is ill-defined, and related data are difficult to put into context. There are four relevant battlefronts, all of interest to risk assessment and prevention. These are: an increasing pool of patients with MRSA discharged from hospitals into the community; MRSA spreading to patients in nursing and residential homes; and MRSA spreading from patients and health-care workers to others in community. There are often difficulties in determing whether the fourth issue, MRSA arising apparently de novo in the community, is in fact due to one of these other fronts. All these battlefronts are important and not yet lost. However, we must agree on definitions and design-appropriate surveillance strategies, so that we can best plan prevention and control activities to contain these emerged or emerging problems" ${ }^{36}$.

\section{ACKNOWLEDGMENTS}

\section{Supported by Research Project MSM 6198959223.}

\section{REFERENCES}

1. Petráš P. Jubilejní padesátý stafylokok, Staphylococcus pettenkoferi. Zprávy CEM (SZÚ, Praha) 2007; 16(7):314-7.

2. Kluytmans J, van Belkum A, Verbrugh H. Nasal Carriage of Staphylococcus aureus: Epidemiology, Underlying Mechanism, and Assosciated Risk. Clin Microbiol Rev 1997; 10(3):505-20.

3. Wenzel RP, Perl TM. The significance of nasal carriage of Staphylococcus aureus and the incidence of postoperative wound infection. J Hosp Infect 1995; 31:13-24.

4. Kuehnert MJ, Kruszon-Moran D, Hill HA, McQuillan G, McAllister K, Fosheim G et al. Prevalence of Staphylococcus aureus Nasal Colonization in the United States, 2001-2002. JID 2006; 193(15):172-9.

5. Creech II CB, Talbot TR, Schaffner W. Community-Associated Methicillin-Resistant Staphylococcus aureus: The Way to the Wound Is through the Nose. J Infect Dis 2006; 193:169-71.

6. Hájek V, Součková A. Koaguláza-pozitivní stafylokoky. In: Bednáŕ M, Fraňková V, Schindler J, Souček A, editors. Lékařská mikrobiologie. Praha: Marvil; 1996. p.194-203.

7. Panton PN, Valentine FCO. Staphylococcal toxin. Lancet 1932; 222:506-8.

8. Machová I, Petráš P, Blažková E, Kňapová L. Sledování genů kódujících Pantonův-Valentinův leukocidin u kmenů Staphylococus aureus. Epidemiol Mikrobiol Imunol 2007; 56(2):88-93.

9. Monecke S, Slickers P, Ellington MJ, Kearns AM, Ehricht R. High diversity of Panton-Valentine leukocidin-positive, methicillin-susceptible isolates of Staphylococcus aureus and implications for the evolution of community-associated methicillin-resistant $S$. aureus. Clin Microbiol Infect 2007; 13(12):1157-64.

10. Voyich JM, Otto M, Mathema B, Braughton KR, Whitney AR, Welty D. et al. Is Panton-Valentine Leukocidin the Major Virulence Determinant in Community-Associated Methicillin-Resistant Staphylococcus aureus Disese? J Infect Dis 2006; 194:1761-70. 
11. Coombs GW, Nimmo GR, Bell JM, Huygens F, O’Brien FG, Malkowski MJ et al. Genetic Diversity among Community Methicillin-Resistant Staphylococcus aureus Strains Causing Outpatient Infections in Australia. J Clin Microbiol. 2004; 42(10):4735-43

12. Zhang K, McClure JA, Elsayed S, Tan J, Conly JM. Coexistence of Panton-Valentine leukocidin-positive and - negative community-associated methicillin-resistant Staphylococcus aureus USA400 sibling strains in a large Canadian health-care region. J Infect Dis 2008; 197(2):195-204.

13. Lowy FD. Staphylococcus aureus infections. N Engl J Med 1998; 339:520-32.

14. Boyle-Vavra S, Daum RS. Community-acquired methicillin-resistant Staphylococcus aureus: the role of Panton-Valentine leukocidin. Laboratory Investigation 2007; 87:3-9.

15. Barber M, Rozwadowska-Dowzenko M. Infection by penicillinresistant staphyloccocci. Lancet 1948; 252:641-4.

16. Rammelkamp M. Resistance of Staphylococcus aureus to the action of penicillin. Proc Soc Exp Biol Med 1942; 51:386-9.

17. Kirby WM. Extraction of a high potent penicillin inactivator from penicillin resistant staphylococci. Science 1944; 99:452-3.

18. Williams REO. Epidemic staphylococci. Lancet 1959; 1:190-5.

19. Jevons MP. „Celbenin“- resistant Staphylococci. BMJ 1961; i:1245.

20. Jungk J, Como-Sabetti K, Stinchfield P, Ackerman P, Harriman K. Epidemiology of Methicillin-Resistant Staphylococcus aureus at a Pediatric Healthcare System, 1991-2003. Pediatr Infect Dis J 2007; 26:339-44.

21. Grundmann H, Aires-de-Sousa M, Boyce J, Tiermersma E. Emergence and resurgence of meticillin-resistant Staphylococcua aureus as a public-health threat. Lancet 2006; 368:874-85.

22. Crowcroft NS, Catchpole M. Mortality from methicillin-resistant Staphylococcus aureus in England and Wales: analysis of death certicicates. BMJ 2002; 325:1390-1.

23. Duckworth GJ, Lothian JL, Williams JD. Methicillin-resistant Staphylococcus aureus: report of an outbreak in a London teaching hospital. J Hosp Infect 1988; 11:1-15.

24. Schwalbe RS, Stapleton JT, Gilligan PH. Emergence of vancomycin resistance in coagulase-negative staphylococci. N Engl J Med 1987; 316:927-31.

25. Hiramatsu K, Hanaki H, Ino T et al. Methicillin-resistant Staphylococcus aureus clinical strains with reduced vancomycin susceptibility. J Antimicrob Chemother. 1997; 40:135-6.

26. Interim Guidelines for Prevention and Control of Staphylococcal Infection Associated with Reduced Susceptibility to Vancomycin. MMWR 1997; 46(27):626-35. Available from: Available from: htp://www.cdc.gov

27. Staphylococcus aureus resistant to vancomycin-United States, 2002. MMWR 2002; 51:565-7. Available from: htp://www.cdc.gov

28. Noble WC, Virani Z, Cree RG. Co-transfer of vancomycin and other resistance genes from Enterococcus faecalis NCTC 12201 to Staphylococcus aureus. FEMS Microbiol Lett 1992; 72:195-8.

29. Clark NC, Cooksey RC, Hill BC, Swenson JM, Tenover FC Characterization of Glycopeptide-Resistant Enterococci from U.S. Hospitals. Antimicrob Agents Chemother 1993; 37(11):2311-17.

30. Ito T, Okuma K, Ma XX, Yuzawa H and Hiramatsu K. Insights on antibiotic resistance of Staphylococcus aureus from its whole genome: genomic island SCC. Drug Resist. Updat 2003; 6:4152.

31. Berger-Bachi B, Rohrer S. Factors influencing methicillin resistance in staphylococci. Arch Microbiol 2002; 178:165-71.

32. Deurenberg RH, Vink C, Kalenic S, Friedrich AW, Bruggeman $\mathrm{CA}$ and Stobberingh EE. The molecular evolution of methicillin-resistant Staphylococcus aureus. Clin Microbiol Infect 2007; 13:222-35.

33. de Sousa MA, de Lencastre H. Bridges from hospitals to the laboratory: genetic portraits of methicillin-resistant Staphylococcus aureus clones. FEMS Immunol Med Microbiol 2004; 40:101-111.

34. Udo EE, Pearman JW, Grubb WB. Genetic analysis of community isolates of methicillin-resistant Staphylococcus aureus in Western Australia. J Hosp Infect 1993; 25(2):97-108.
35. Herold BC, Immergluck LC, Maranan MC, Lauderdale DS, Gaskin RE, Boyle-Vavra S et al. Community-Acquired MethicillinResistant Staphylococcus aureus in Children With No Identified Predisposing Risk. JAMA 1998; 279(8):593-8.

36. Cookson BD. Methicillin-Resistant Staphylococcus aureus in the Community: New Battlefronts, or Are the Battles Lost? Infect Control Hosp Epidemiol 2000; 21:398-403.

37. Suntharam N, Hacek D, Peterson LR. Low Prevalence of Community-Aquired Methcillin-Resistant Staphylococcus aureus in Adults at a University Hospital in the Central United States. J Clin Microbiol 2001; 39(4):1669-71.

38. Nakamura MM, Rohling KL, Shashaty M, Lu H, Yi-Wei Tang, Edwards KM. Prevalence of methicillin-resistant Staphylococcus aureus in the community pediatric population. Pediatr Infect Dis J 2002; 21(10):917-21.

39. Salgado CD, Farr BM, Calfee DP. Community-Acquired Methicillin-Resistant Staphylococcus aureus: A Meta-Analysis of Prevalence and Risk Factors. Clin Infect Dis 2003; 36:131-9.

40. Witte W, Cuny C, Strommenger B, Braulke C, Heuck D. Emergence of a new community acquired MRSA strain in Germany. Eurosurveillance 2004; 9(1):16-18. Available from: http://www.uerosurveillance.org

41. Ellis MW, Hospenthal DR, Dooley DP, Gray PJ, Murray CK. Natural History of Community-Acquired Methicillin-Resistant Staphylococcus aureus Colonization and Infection in Soldiers. Clin Infect Dis 2004; 39:971-9.

42. Dietrich DW, Auld DB, Mermel LA. Community-Acquired Methicillin-Resistant Staphylococcus aureus in Southern New England Children Pediatrics 2004; 113(4):347-52.

43. Denis O, Malaviolle X, Titeca G, Struelens MJ, Garrino MG Glupczynski $\mathrm{Y}$ et al. Emergence of Panton-Valentine leukocidin positive community-aquired MRSA infections in Belgium. Eurosurveillance Weekly 2004; 6(24). Available from: http://www. uerosurveillance.org

44. Tatsuo Y. Panton-Valentine leukocidin positive community-aquired MRSA infection in Japan. Eurosurveillance Weekly 2004; 8(27). Available from: http://www.uerosurveillance.org

45. Vourli S, Perimeni D, Makri A, Polemis M, Voyiatzi A, Vatopoulos A. Community acquired MRSA infections in a paediatric population in Greece. Eurosurveillance Weekly 2005; 10(4-6):78-9. Available from: http://www.uerosurveillance.org

46. Ribeiro A, Dias C, Silva-Carvalho MC, Berquó L, Ferreira FA, Santos RNS et al. First Report of Infection with CommunityAcquired Methicillin-Resistant Staphylococcus aureus in South America. J Clin Microbiol 2005; 43(4):1985-8.

47. Mulvey MR, MacDougallL, Cholin B, Horsman G, Fidyk M, Woods S et al. Community-associated Methicillin-resistant Staphylococcus aureus, Canada. Emerg Infect Dis 2005; 11(6):84450

48. Harbarth S, Francois P, Schrenzel J, Fankhauser-Rodriguez C, Hudonnet S, Koessler T et al. Community-associated Methicillinresistant Staphylococcus aureus, Switzerland. Emerg Infect Dis 2005 ; 11(6):962-5.

49. Weber JT. Community-Associated Methicillin-Resistant Staphylococcus aureus. Clin Infect Dis 2005; 41(Suppl 4):S269S272.

50. Wannet WJB, Spalburg E, Heck MEOC, Pluister GN, Tiemersma E, Willems RJL et al. Emergence of Virulent Methicillin-Resistant Staphylococcus aureus Strains Carrying Panton-Valentine Leucocidin Genes in The Netherlands. J Clin Microbiol 2005; 43(7):3341-5.

51. Community-Associated Methicillin-Resistant Staphylococcus aureus Infection Among Healthy Newborns in Chicago and Los Angeles County, 2004. MMWR 2006; 55(12):329-32. Available from: htp://www.cdc.gov

52. Saiman L, O'Keefe M, Graham PL, Wu F, Said-Salim B, Kreisswirth B et al. Hospital Transmission of Community-Aquired Methicillin-Resistant Staphylococcus aureus among Postpartum Women. CID 2003; 37(10):1313-19.

53. Nimmo GR, Coombs GW, Pearson JC, O’Brien FG, Christiansen KJ, Turnidge JD et al. Methicillin-resistant Staphylococcus aureus 
in the Australian community: an evolving epidemic. MJA 2006; 184(8):384-8

54. King MD, Humphrey BJ, Wang YF, Kourbatova EV, Ray SM, Blumberg HM. Emergence of Community-Acquired MethicillinResistant Staphylococcus aureus USA 300 Clone as the Predominant Cause of Skin and Soft-Tissue Infections. Ann Intern Med 2006; 144:309-17.

55. Kuint J, Barzilai A, Regev-Yochay G, Rubinstein E, Keller N, Maayan-Metzger A. Comparison of community-acquired methicillin-resistant Staphylococcus aureus bacteremia to other staphylococcal species in a neonatal intensive unit. Eur J Pediatr 2007; 166:319-25.

56. Machová I, Petráš P. První potvrzení přítomnosti genů kódujících Pantonův-Valentinův leukocidin u českých kmenů Staphylococcus aureus. Zprávy CEM (SZÚ, Praha) 2004; 13(9):387-8.

57. Fey PD, Said-Salim B, Rupp ME, Hinrichs SH, Boxrud DJ, Davis $\mathrm{CC}$ et al. Comparative Molecular Analysis of Community- or Hospital Acquired Methicillin-Resistant Staphylococcus aureus. Antimicrob Agents Chemother 2003; 47 (1):196-203.

58. Huygens F, Stephens AJ, Nimmo GR, Giffard PM. mecA Locus Diversity in Methicillin-Resistant Staphylococcus aureus Isolates in Brisbane, Australia, and the Development of a Novel Diagnostic Procedure for the Western Samoan Phage Pattern Clone. J Clin Microbiol 2004; 42(5):1947-55

59. Coombs GW, Nimmo GR, Bell JM, Huygens F, O’Brien FG, Malkowski MJ et al. Genetic Diversity among Community Methicillin-Resistant Staphylococcus aureus Strains Causing Outpatient Infections in Australia. J Clin Microbiol 2004; 42(10):4735-43.

60. Said-Salim B, Mathema B, Braughton K, Davis S, Sinsimer D, Eisner W et al. Differential Distribution and Expression of PantonValentine Leucocidin among Community-Acquired MethicillinResistant Staphylococcus aureus Strains. J Clin Microbiol 2005; 43(7):3373-9.

61. Po-Liang Lu, Lien-Chun Chin, Chien-Fang Peng, Yi-Hsiung Chiang, Tyen-Po Chen, Ling Ma et al. Risk Factors and Molecular Analysis of Community Methicillin-Resistant Staphylococcus aureus Carriage. J Clin Microbiol 2005; 43(1):132-9.

62. Zaoutis TE, Toltzis P, Chu J, Abrams T, Dul M, Kim J et al. Clinical and Molecular Epidemiology of Community-Acquired Methicillin-Resistant Staphylococcus aureus Infections Among Children With Risk Factors for Health Care-Associated Infection 2001-2003. Pediatr Infect Dis J 2006; 25(4):343-8.

63. Diep BA, Carleton HA, Chang RF, Sensabaugh GF, PerdreauRemington F. Roles of 34 Virulence Genes in the Evolution of Hospital- and Community-Associated Strains of MethicillinResistant Staphylococcus aureus. J Infect Dis 2006; 193:1495 1503.

64. Tristan A, Bes M, Meugnier H, Lina G, Bozdogan B, Courvalin P et al. Global Distribution of Panton-Valentine Lekocidin-positive Methicillin-resistant Staphylococcus aureus, 2006. Emerg Infect Dis 2007; 13(4):594-600.

65. Popovich K, Hota B, Rice T, Aroutcheva A, Weinstein RA Phenotypic Prediction Rule for Community-Associated Methicillin-Resistant Staphylococcus aureus. . J Clin Microbiol 2007; 45(7):2293-5

66. Huang YH, Tseng SP, Hu JC, Hsueh PR, Teng LJ. Clonal spread of SCCmec type IV methicillin-resistant Staphylococcus aureus between community and hospital. Clin Microbiol Infect 2007; 13:717-24.

67. Davis SL, Perri MB, Donabedian SM, Manierski C, Singh A, Vager D. et al. Epidemiology and Outcomes of CommunityAssociated Methicillin-Resistant Staphylococcus aureus Infection. J Clin Microbiol 2007; 45:1705-11.

68. Larsen AR, Stegger M, Goering RV, Sorum M, Skov R. Emergence and dissemination of the methicillin resistant Staphylococcus aureus USA300 clone in Denmark (2000-2005). Euro Surveill 2007; 12(2): Available from: http://www.eurosurveillance.org

69. Miller LG, Quan C, Shay A, Mostafaie K, Bharadwa K, Tan N. et al. A Prospective Investigation of Outcomes after Hospital Discharge for Endemic Community-Acquired Methicillin-Resistant
and-Susceptible Staphylococcus aureus Skin Infection. Clin Infect Dis 2007; 44(15):483-92.

70. Durupt F, Mayor L, Bes M, Reverdy M-E, Vandenesch F, Thomas $\mathrm{L}$ et al. Prevalence of Staphylococcus aureus toxins and nasal carriage in furuncles and impetigo. Br J Dermatol 2007; 157:1161-7.

71. Kazakova SV, Hageman JC, Matava M, Srinivasan A, Phelan L, Garfinkel B et al. A clone of methicillin-resistant Staphylococcus aureus among professional footbal players. N Engl J Med 2005; 352(5):468-75

72. Kurkowski Ch. CA-MRSA The New Sports Pathogen. Orthopaedic Nursing 2007; 26(5):310-6.

73. Zinderman CE, Conner B, Malakooti MA, LaMar JE, Armstrong A, Bohnker BK. Community-acquired methicillin-resistant Staphylocccus aureus among military recruits. Emerg Infect Dis 2004; 10:941-4.

74. CDC. Department of Health and Human Services. CommunityAssociated MRSA information for Clinicians. Date last modified: February 3, 2005. Available from: http://www.cdc.gov.

75. Klevens RM, Morrison MA, Nadle J, Petit S, Gershman K, Ray $\mathrm{S}$ et al. Invasive Methicillin-Resistant Staphylocccus aureus Infections in the United States. JAMA 2007; 298(15):1763-71.

76. CDC. Department of Health and Human Services. Laboratory Detection of Oxacillin/Methicillin-resistant Staphylococcus aureus. February 2, 2005. Available from: http://www.cdc.gov/ncidod/hip/ Lab/FactSheet/mrsa.htm

77. Clinical Microbiology Product Catalog, International Edition 2007-2008 , BIO-RAD, p.11,16.

78. Nsira SB, Dupuis M, Leclerq R. Evaluation of MRSA Select, a new chromogenic medium for the detection of nasal carriage of methicillin-resistant Staphylococcus aureus. Int J Antimicrob Agents 2006; 27:561-4.

79. van Loo IH, van Dijk S, Verbakel-Schelle I, Buiting AG. Evaluation of a chromogenic agar (MRSASelect) for the detection of methicillin-resistant Staphylococcus aureus with clinical samples in The Netherlands. J Med Microbiol 2007; 56(Pt 4):491-4.

80. Cherkaoui A, Renzi G, Francois P, Schrenzel J. Comparison of four chromogenic media for culture-based screening of methicillin-resistant Staphylococcus aureus. J Med Microbiol 2007; 56(Pt 4):500-3

81. Stoakes L, Reyes R, Daniel J, Lennox G, John MA Lannigan $\mathrm{R}$ et al. Prospective Comparison of a New Chromogenic Medium, MRSASelect, to CHROMagar and Mannitol-Salt Medium Suplemented with Oxacillin or Cefoxitin for Detection of Methicillin-Resistant Staphylococcus aureus. J Clin Microbiol 2006; 44(2):637-9

82. European clinical laboratory (ECL) 2002; 27:28

83. ORSAB, Oxacillin Resistance Screening Agar Base. Available from: http://www.oxoid.com

84. Apfalter P, Assadian O, Kalczyk A, Lindenmann V, Makristathis A, Mustafa S et al. Performance of a new chromogenic oxacillin resistance screen medium (Oxoid) in the detection and presumptive identification of methicillin-resistant Staphylococcus aureus. Diagn Microbiol Infect Dis. 2002; 44:209-211.

85. Available from: http://www.biomerieux-diagnostics.com

86. Perry JD, Davies A, Butterworth LA, Hopley ALJ, Nicholson A Gould FK. Development and Evaluation of a Chromogenic Agar Medium for Methicillin-Resistant Staphylococcus aureus. J Clin Microbiol 2004; 42(10):4519-23.

87. Compernolle V, Verschraegen G, Claeys G. Combined Use of Pastorex Staph-Plus and Either of Two New Chromogenic Agars, MRSA ID and CHROMagar MRSA, for Detection of MethicillinResistant Staphylococcus aureus. J Clin Microbiol 2007; 45 (1):154

88. Brakstad OG, Aasbakk K, Maeland JA. Detection of Staphylococcus aureus by Polymerase Chain Reaction Amplification of the nuc Gene. J Clin Microbiol 1992; 30(7):1654-60.

89. Huletsky A, Giroux V, Rossbach M, Gagnon M, Vaillancourt M, Bernier F. et al. New real-time PCR assay for rapid detection of methicillin-resistant Staphylococcus aureus directly from specimens containing a mixture of staphylococci. J Clin Microbiol 2004; 42:1875-84. 
90. Desjardins M, Guibord Ch, Lalonde B, Toye B, Ramotar K. Evaluation of the IDI-MRSA Assay for Detection of MethicillinResistant Staphylococcus aureus from Nasal and Rectal Specimens Pooled in a Selective Broth. J Clin Microbiol 2006; 44(4):121923.

91. de San N, Denis O, Gasasira M-F, De Mendonca R, Nonhoff C, Struelens MJ. Controlled Evaluation of the IDI-MRSA Assay for Detection of Colonization by Methicillin-Resistant Staphylococcus aureus in Diverse Mucocutaneous Specimens. J Clin Microbiol 2007; 45(4):1098-101.

92. van Hal SJ, Stark D, Lockwood B, Marriott D, Harkness J. Methicillin-Resistant Staphylococcus aureus (MRSA) Detection: Comparison of Two Molecular Methods (IDI-MRSA PCR Assay and GenoType MRSA Direct PCR Assay) with Three Selective MRSA Agars (MRSA ID, MRSASelect, and CHROMagar MRSA) for Use with Infection-Control Swabs. J Clin Microbiol 2007; 45(8):2486-90.

93. Hardy KJ, Szczerpura A, Davies R, Bradbury A, Stallard N, Gossain $\mathrm{S}$ et al. A study of the efficacy and cost-effectiveness of MRSA screening and monitoring on surgical wards using a new, rapid molecular test (EMMS). Available from: http://www.biomedcentral.com

94. Stamper PD, Cai M, Howard T, Speser S, Carroll KC. Clinical Validation of the Molecular BD GeneOhm StaphSR Assay for Direct Detection of Staphylococcus aureus and MethicillinResistant Staphylococcus aureus in Positive Blood Cultures. J Clin Microbiol 2007; 45(7):2191-6.

95. Cosgrove SE, Sakoulas G, Perencevich EN, Schwaber MJ, Karchmer AW and Carmeli Y. Comparison of mortality associated with methicillin-resistant and methicillin-susceptible Staphylococcus aureus bacteremia: a meta-analysis. Clin Infect Dis. 2003; 36:539.

96. Cosgrove SE. The relationship between antimicrobial resistance and patient outcomes: mortality, length of hospital stay, and health care costs. Clin Infect Dis 2006; 42 (Suppl. 2):582-9.

97. Girou E, Pujade G, Legrand P, Cizeau F, Brun-Buisson C. Selective screening of carriers for control of methicillin-resistant Staphylococcus aureus (MRSA) in high-risk hospital areas with a high level of endemic MRSA. Clin Infect Dis 1998; 27:543-50.

98. Šrámová H, Nyč O, Hrončeková J, Cipra P. Výskyt multirezistetních kmenů ve FN Motol. Zprávy CEM (SZÚ, Praha) 2003; 12(11):476-80.

99. Oie S, Suenaga S, SawaA, Kamiya A. Association between Isolation Sites of Methicillin-Resistant Staphylococcus aureus (MRSA) in Patients with MRSA-Positive Body Sites and MRSA Contamination in Their Surounding Environmental Surfaces. Jpn J Infect Dis 2007; 60:367-9.

100. Tomic V, Svetina Sorli P, Trinkaus D, Sorli J, Widmer AF. Comprehensive strategy to prevent nosocomial spread of methicillin-resistant Staphylococcus aureus in highly endemic setting. Arch Intern Med 2004; 164:2038-43.

101. Lucet JC, Grenet K, Armand-Lefevre L, Harnal M, Bouvet E, Regnier B et al. High prevalence of carriage methicillin-resistant Staphylococcus aureus at hospital admission in elderly patients: implications for infection control strategies. Infect Control Hosp Epidemiol 2005; 26:121-6.

102. Johnson PDR, Martin R, Burrell LJ, Grabsch EA, Kirsa SW, O'Keeffe J et al. Efficacy of an alcohol/chlorhexidine hand hygiene program in a hospital with high rates of nosocomial methicillinresistant Staphylococcus aureus (MRSA) infection. MJA 2005; 183(10):509-14.

103. Klein E, Smith DL, Laxminarayan R. Hospitalizations and Deaths Caused by Methicillin-Resistant Staphylococus aureus, United States, 1999-2005. Emerg Infect Dis. 2007; 13:1840-6.

104. Yu VL, Goetz A, Wagener M, Smith PB, Rihs JD, Hanchett J et al. Staphylococcus aureus carriage and infection in patients on hemodialysis. N Engl J Med 1986; 315:91-6.

105. Muto CA, Jernigan JA, Ostrowsky BE, Richet HM, Jarwis WR, Boyce JM et al. SHEA Guideline for Preventing Nosocomial Transmission of Multidrug-Resistant Strains Staphylococcus aureus and Enterococcus. Infect Control Hosp Epidemiol 2003; 24:36286.
106. Wenzel RP, Perl TM. The significance of nasal carriage of Staphylococcus aureus and the incidence of postoperative wound infection. J Hosp Infect 1995;31:13-24.

107. Muder RR, Brennen C, Wagener MM, Vickers JD, Rihs GA, Hancock YC et al. Methicillin-resistant staphylococcal colonization and infection in a long-term care facility. Ann Intern Med 1991; 114:107-12.

108. van Belkum A, Ewmonts M, Wertheim H, de Jongh Ch, Nouwen $\mathrm{J}$, Bartels $\mathrm{H}$ et al. The role of human innate immune factors in nasal colonization by Staphylococcus aureus. Microbes Infect 2007; 9:1471-7.

109. Cepeda JA, Whitehouse T, Cooper B et al. Isolation of patiens in single rooms or cohorts to reduce spread of MRSA in intensivecare units: prospective two-centre study. Lancet 2005; a365:295304.

110. Rosdahl VT, Knudsen AM. The decline of methicillin resistance among Danish Staphylococcus aureus strains. Infect Control J Hosp Epidemiol 1991; 12:83-8.

111. EARSS Management Team: EARSS Annual Report 2006. Bilthoven, The Netherlands, October 2007; 45-58.

112. Verhoef J, Beaujean D Blok H et al. A Dutch approach to methicillin-resistant Staphylococcus aureus. Eur J Clin Microbiol Infect Dis 1999; 18:461-6.

113. Salmenlinna S, Lyytikainen O, Kotilainen P, Scotford R, Siren E, Vuopio-Varkila J. Molecular epidemiology of methicillin-resistant Staphylococcus aureus in Finland. Eur J Clin Microbiol Infect Dis 2000; 19:101-7.

114. Cunningham R, Jenks P, Northwood J, Wallis M, Ferguson S, Hunt S. Effect on MRSA transmission of rapid PCR tetsting of patients admitted to critical care. J Hosp Infect 2007; 65(1):248.

115. Widmer AF, Mertz D, Frei R. Necessity of Screening of both the Nose and the Throat To Detect Methicillin-Resistant Staphylococcus aureus Colonization in Patients upon Admission to an Intensive Care Unit. J Clin Microbiol 2008; 46(2):835.

116. Noskin GA, Rubin RJ, Schentag JJ, Kluytmans J, Hedblom EC, Jacobson C et al. Budget Impact Analysis of Rapid Screening for Staphylococcus aureus Colonization Among Patients Undergoing Elective Surgery in US Hospitals. Infect Control Hosp Epidemiol 2008; 29(1):16-24.

117. Nakaminami H, Noguchi S, Nishijima S, Kurokawa I, So H, Sasatsu M. Transduction of the Plasmid Encoding Antiseptic Resistance Gene qacB in Staphylococcus aureus. Biol Pharm Bull 2007; 30(8):1412-15

118. Narui K, Takano M, Noguchi N, Sasatsu M. Susceptibilities of Methicillin-Resistant Staphylococcus aureus Isolates to Seven Biocides. Biol Pharm Bull 2007; 30(3):585-7.

119. Siegel JD, Rhinehart E, Jackson M, Chiarello L. Guideline for Isolation Precaution: Preventing Transmission of Infectious Agents in Healthcare Settings June 2007. Available from: http://www.cdc. gov/ncidod/dhap/isolation2007.pdf

120. Humphreys H. National guidelines for the control and prevention of methicillin-resistant Staphylococcus aureus what do they tell us? Clin Microbiol Infect 2007; 13:846-53.

121. Bergerová T, Hedlová D, Jindrák V, Urbášková P, Chmelík V. Doporučený postup pro kontrolu výskytu kmenů Staphylococcus aureus rezistentních $\mathrm{k}$ oxacilinu (MRSA) a s jinou nebezpečnou antibiotickou rezistencí ve zdravotnických zařízeních. Zprávy CEM (SZÚ, Praha) 2006: 15(př́loha 1):1-16.

122. Popovich KJ, Hota B. Treatment and prevention of community-associated methicillin-resistant Staphylococcus aureus skin and soft tissue infections. Dermatol Ther 2008; 21:167-79.

123. Bartels MD, Boye K, Larsen AR, Skov, Westh H. Rapid Increase of Genetically Diverse Methicillin-Resistant Staphylococcus aureus, Copenhagen, Denmark. Emerg Infect Dis 2007 Oct; [Epub ahead of print]

124. Kampf G, Kramer A. Eradication of methicillin-resistant Staphylococcus aureus with an antiseptic soap and nasal mupirocin among colonized patients-an open uncontrolled clinical trial. Ann Clin Microbial Antimicrob 2004;3:9.

125. Vasquez JE, Walker ES, Franzus BW, Overbay BK, Reagan DR, Sarubbi FA. The Epidemiology of Mupirocin Resistance Among 
Methicillin-Resistant Staphylococcus aureus at a Veterans` Affairs Hospital. Infect Control Hosp Epidemiol 2000; 21:459-64.

126. Diep BA, Gill SR, Chang RF, Phan THV, Chen JH, Davidson MG et al. Complete genome sequence of USA300, an epidemic clone of community-acquired methicillin-resistant Staphylococcus aureus. Lancet 2006; 367:731-9.

127. Ridenour G, Lampen R, Federspiel J, Kritchevsky S, Wong E, Climo M. Selective Use of Intranasal Mupirocin and Chlorhexidine Bathing and the Incidence of Methicillin- Resistant Staphylococcus aureus Colonization and Infection Among Intensive Care Unit Patients. Infect Control Hosp Epidemiol 2007; 28:1155-61.

128. Wendt C, Schinke S, "Württemberger M, Oberdorfer K, BockHensley O, von Baum H. Value of Whole-Body Washing With Chlorhexidine for the Eradication of Methicillin- Resistant Staphylococcus aureus: A Randomized, Placebo-Controlled, Double-Blind Clinical Trial. Infect Control Hosp Epidemiol 2007; 28:1036-43.

129. Boswell TC, Fox PC. Reduction in MRSA environmental contamination with a portable HEPA-filtration unit. J Hosp Infect 2006; 63(1):47-54.

130. Sexton T, Clarke P, O’Neill E, Dillane T, Humphreys H. Environmental reservoirs of methicillin-resistant Staphylococcus aureus in isolation rooms: correlation with patient isolates and implications for hospital hygiene. J Hosp Infect 2006; 62(2):18794.

131. Siegel JD, Rhinehart E, Jackson M, Chiarello L. Management of Multigrug-Resistant Organisms In Healthcare Settings, 2006. Available from: http://www.cdc.gov/ncidod/dhap/isolation2007. pdf

132. Dellit T, Duchin J, Hofmann J, Olson EG. Interim Guideline for Evaluation and Management of Community-Associated MethicilinResistant Staphylococcus aureus Skin and Soft Tissue Infection in Outpatient Settings. Infect Dis Soc Washington 2004; 2:1-14.

133. ČSN EN ISO 14644-1,2,4 Čisté prostory a příslušné řízené prostředí

134. Vyhláška č. 195/2005 Sb., kterou se upravují podmínky předcházení vzniku a šiření infekčních onemocnění a hygienické požadavky na provoz zdravotnických zařízení a ústavů sociální péče.

135. Pittet D, Hugonnet S, Harbarth S, Mourouga P, Sauvan V, Touveneau $\mathrm{S}$ et al. Effectiveness of a hospital-wide programme to improve compliance with hand hygiene. Lancet 2000; 356:130712.

136. Christiaens G, Barbier C, Mutsers J, WarnotteJ, De Mol, Bouffioux C. Hand hygiene: first measure to control nosocomial infection. Rev Med Liege 2006; 61(1):31-6.

137. Girou E., Legrand P, Soing-Altrach S, Lemire A, Poulain C, Allaire $\mathrm{A}$ et al. Association between hand hygiene compliance and methicillin-resistant Staphylococcus aureus prevalence in a French rehabilitation hospital. Infect Control Hosp Epidemiol 2006; 27(10):1128-30.

138. Lai KK, Fontecchio S, Melvi Z, Baker SP. Impact of alcoholbased, waterless hand antiseptic on the incidence of infection and colonization with methicillin-resistant Staphylococcus aureus and vancomycin-resistant enterococci. Infect Control Hosp Epidemiol 2006; 27(10):1018-24.

139. Gordin FM, Schultz ME, Huber RA, Gill JA. Reduction in nosocomial transmission of drug-resistant bacteria after introduction of an alcohol-based handrub. Infect Control Hosp Epidemiol 2005; 26(7):650-3.

140. Boyce JM, Pittet D. Guideline for hand hygiene in health-care settings: recommedations of the Healthcare Infection Control Practices Advisory Committee and the HICPAC/SHEA/ APIC/IDSA Hand Hygiene Task Force, Society for Healthcare Epidemiology of America/Association for Professionals in Infection Control/Infectious Diseases Society of America. MMWR Recomm Rep 2002; 51:1-45.

141. Rouch DA, Cram DS, DiBerardino D, Littlejohn TG, Skurray RA. Efflux-mediated antiseptic resistance gene qacA from Staphylococcus aureus: common ancestry with tetracycline- and sugar-transport proteins. Mol Microbiol 1990; 4(12):2051-62.
142. Bjorland J, Sunde M, Waage S. Plasmid-borne $s m r$ gene causes resistance to quaternary ammonium compouds in bovine Staphylococcus aureus. J Clin Microbiol 2001;39(11): 3999-4004.

143. Nakaminami H, Noguchi S, Nishijima S, Kurokawa I, So H, Sasatsu M. Transduction of the Plasmid Encoding Antiseptic Resistance Gene qacB in Staphylococcus aureus. Biol Pharm Bull 2007; 30(8):1412-15

144. Narui K, Takano M, Noguchi N, Sasatsu M. Susceptibilities of Methicillin-Resistant Staphylococcus aureus Isolates to Seven Biocides. Biol Pharm Bull 2007; 30(3):585-7.

145. Smith K, Gemmell CG, Hunter IS. The association between biocide tolerance and the presence or absence of qac gene among hospital-acquired and community-acquired MRSA isolates. J Antimicrob Chemother. 2007 Nov 2 [Epub ahead of print]

146. Nimmo GR, Coombs GW, Pearson JC, O’Brien FG, Christiansen KJ, Turnidge JD et al. Methicillin-resistant Staphylococcus aureus in tne Australian community. An evolving epidemic. Med J Australia 2006; 184(8):384-8.

147. Věstník MZ ČR částka 9/2005 - Metodické opatření: Hygienické zabezpečení rukou ve zdravotní péči.

148. ČSN EN 1499 Chemické dezinfekční př́ipravky a antiseptika - Dezinfekční mytí rukou - Zkušební metoda a požadavky (fáze 2/stupeň 2).

149. CSN EN 1500 Chemické dezinfekční přípravky a antiseptika - Hygienická dezinfekce rukou - Zkušební metoda a požadavky (fáze 2 /stupeň 2).

150. Humphreys H. Can we do better in controlling and preventing methicillin-resistant Staphylococcus aureus (MRSA) in the intensive care unit (ICU)? Eur J Clin Microbiol Infect Dis 2008; 27:40913 .

151. Shiomori T, Miyamoto H, Makishima K, Yoshida M, Fujiyoshi $\mathrm{T}$, Udaka $\mathrm{T}$ et al. Evaluation of bedmaking-related airborne and surface methicillin-resistant Staphylococcus aureus contamination. J Hosp Infect 2002; 50(1):30-5.

152. Shiomori T, Miyamoto H, Makishima K. Significance of airborne transmission of methicillin-resistant Staphylococcus aureus in an otolaryngology-head and neck surgery unit. Arch Otolaryngol Head Neck Surg 2001; 127(6):644-8.

153. Oie S, Hosokawa I, Kamiya A. Contamination of room door handles by methicillin-sensitive/methicillin-resistant Staphylococcus aureus. J Hosp Infect 2002; 51(2):140-3.

154. Sexton T, Clarke P, O’Neill E, Dillane T, Humphreys H. Environmental Reservoirs of methicillin-resistant Staphylococcus aureus in isolation rooms: correlation with patients isolates and implications for hospital hygiene. J Hosp Infect 2006; 62(2): 18794.

155. Dancer SJ. Importance of the environment in methicillin-resistant Staphylococcus aureus acquisition: the case for hospital cleaning. Lancet Infect Dis 2008; 8:101-13.

156. French GL, Otter JA, Shannon KP, Adams NM, Watling D, Parks MJ. Tackling contamination of the hospital environment by methicillin-resistant Staphylococcus aureus (MRSA): a comparison between conventional terminal cleaning and hydrogen peroxide vapour decontamination. J Hosp Infect 2004; 57:31-7.

157. Bures S, Fishbain JT, Uyehara CF, Parker JM, Berg BW. Computer keyboards and faucet handles as reservoirs of nosocomial pathogens in the intensive care unit. Am J Infect Control 2000; 28(6):465-71.

158. Sanders S. The stethoscope and cross-infection revisited. British J General Practice 2005; 54-5.

159. Guinto CH, Bottone EJ, Raffalli JT, Montrcalvo MA, Wormser GP. Evaluation of dedicated stethoscopes as a potential source of nosocomial pathogens. Am J Infect Control 2002; 30(8):499502 .

160. Bernard L, Kereveur A, Durand D, Gonot J, Goldstein F, Luc J et al. Bacterial Contamination of Hospital Physicians' Stethoscope. Infect Control Hosp Epidemiol 1999; 20:625-8.

161. Oomaki M, Yorioka K, Oie S, Kamiya A. Staphylococcus aureus contamination on the surface of working tables in ward staff centers and its preventive methods. Biol Pharm Bull 2006; 29(7):150810 . 
162. Weber SG, Huang SS, Oriola S, Huskins WC, Noskin GA, Harriman K et al. Legislative Mandates for Use of Active Surveillance Cultures to Screen for Methicillin-Resistant Staphylococcus aureus and Vancomycin-Resistant Enterococci: Position Statement From the Joint SHEA and APIC Task Force. Am J Infect Control 2007; 35(2):73-85.

163. Muto CA, Jernigan JA, Ostrowsky BE, Richet HM, Jarvis WR, Boyce JM et al. SHEA Guideline for Preventing Nosocomial Transmission of Multidrug-Resistant Strains of Staphylococcus aureus and Enterococcus. Infect Control Hosp Epidemiol 2003; 24(5):362-86
164. Kneiflová J, Hůrková K, Šimečková E, Petráš P. Záchyt kmene Staphylococcus aureus s vysokou odolností vůči chloru z vody plaveckého stadionu. Zprávy CEM (SZÚ, Praha) 2000; 9(8):32232.

165. Kuroda M, Ohta T, Uchiyama I, Baba T, Yuzawa H, Kobayashi I et al. Whole genome sequencing of methicillin-resistant Staphylococcus aureus. Lancet 2001; 357(21):1225-40.

166. EARSS Annual Report 2006. The Netherland, October 2007, 5455, 104-105.

167. Urbášková P,Macková B,JakubůV,Žemličková $H$ a účastníci CZEARSS. Surveillance antibiotické rezistence invazivních izolátů Staphylococus aureus v rámci EARSS. Zprávy CEM (SZÚ, Praha) 2006;15(5):200-203. 